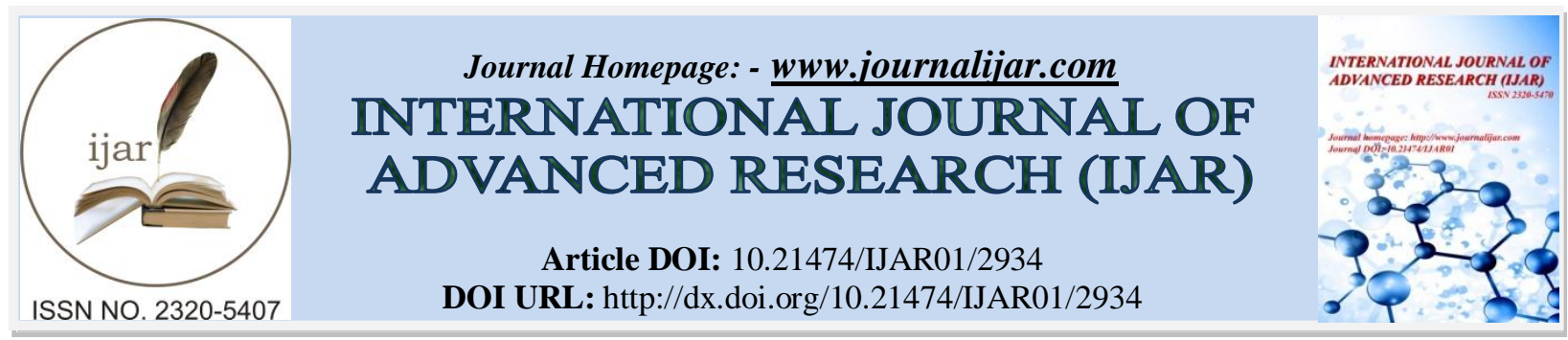

RESEARCH ARTICLE

\title{
TITLE OF THE PAPER - PRELIMINARY PHYTOCHEMICAL ANALYSIS OF DIFFERENT SOLVENT EXTRACTS OF LAGENARIA SICERARIA (MOLINA) STANDL. AND LUFFA CYLINDRICA (L.) M.ROEM VEGETABLE PEEL WASTE.
}

\author{
Shivani C. Kakkar ${ }^{1}$ and Meeta A. Bhot ${ }^{2}$.
}

1. Shivani C. Kakkar, Department of Biotechnology, Birla College, Kalyan.

2. Meeta A. Bhot, Associate Professor, Department of Botany, Birla College, Kalyan.

\section{Manuscript Info}

\section{Manuscript History}

Received: 25 November 2016

Final Accepted: 27 December 2016

Published: January 2017

\section{Key words:-}

Phytochemical, Lagenaria siceraria(Molina) standl., Luffa cylindrica (L.) M.Roem.peels.

\begin{abstract}
Indiais the second major producer of fruits and vegetables in the world. According to India Agricultural Research Data Book 2004, the total waste generated from fruits and vegetables comes to 50 million tons per annum. Peel waste is a serious problem to the processing industries and pollution monitoring agencies. Waste utilization in fruits and vegetable processing industries is the one of the important and challengeable job around the world. The effect of resources depletion and environmental concerns have triggered new regulations and growing awareness throughout the world, thus promoting the use of more and more fruit and vegetable waste to obtain by-products with health benefits. Thus, in the present study an attempt was made to bring the utilization of two vegetable peel waste by investigating the presence of various phytochemicals in the different extracts of Lagenaria siceraria(Molina) standl. and Luffa cylindrica (L.) M.Roem.peels.Ten different extracts of the selected vegetable peels were made using water and organic solvents. Various phytoconstituents were found to be present in different extracts of Lagenaria siceraria(Molina) standl. and Luffa cylindrica (L.)M.Roem.peels.
\end{abstract}

Copy Right, IJAR, 2016,. All rights reserved.

\section{Introduction:-}

Plants are the essential and integral part in medicine because of their ability to form secondary metabolites like proteins, flavonoids, alkaloids, steroids and phenolic substances that are in turn used to restore health and heal many diseases[1]. Food of plant origin is capable of contributing appreciable quantities of nutrients, including proteins needed by both children and adults [2].

In various plants, fruits and vegetables form the rich source of bioactive molecules and are considered to be rich in antioxidants due to presence of compounds like polyphenols and vitamins, which play an important role in scavenging of free radicals [3].

Waste are generated in many forms and at various stages, ranging from domestic to industrial processing and its improper disposal has detrimental effects on the environment as well as human life. It has been observed that of the

Corresponding Author:- Shivani C. Kakkar.

Address:- Shivani C. Kakkar, Department of Biotechnology, Birla College, Kalyan. 
enormous supply of food for human consumption, about one-third gets wasted globally. India, with rich agricultural resources, accounts for $50 \mathrm{MT}$ of vegetable waste which is about $30 \%$ of its total production [4].

Waste generated from food industries is a source of an untapped energy which is mostly dumped inland fills whereby it releases greenhouse gases into an atmosphere. It is very difficult to treat and recycle food waste due to its composition. These wastes lead to increasing waste disposal problem and can pose severe pollution problems and represent a loss of valuable biomass and nutrients [5].Thus, there is an increased attention in bringing useful products from waste material. Suitable methods have to be adopted to utilize them for the conversion into valueadded products [6].

Thus, in the present study an attempt was made to bring the utilization of Lagenaria siceraria(Molina) standl. and Luffa cylindrica (L.) M.Roem. vegetable peelwaste by detecting the presence of various phytochemicals in the different extracts.

\section{Material and Methods:-}

\section{Collection of Sample:-}

The vegetables of Lagenaria siceraria(Molina) standl. and Luffa cylindrica L. M.Roem. used in the present study were collected from the local market of Kalyan. These vegetables were identified from the Department of Botany, Agharkar Institute, Pune.The peels of these vegetables were washed properly under running tap water to remove dust particles. The peels were thenshade dried for 5 days and once the moisture was reduced the peels were then completely dried in an oven at $50^{\circ} \mathrm{C}$. The dried peels were then powdered using grinder and stored in air tight bottles.

\section{Preparation of peel extracts:- Aqueous extract:-}

$5 \mathrm{gm}$ of dry peels powder were suspended in $50 \mathrm{ml}$ ofdistilled water. Extraction was done in orbital shaker at 100 $\mathrm{rpm}\left(25^{\circ} \mathrm{C}\right)$ for $60 \mathrm{mins}$, followed by filtering of the extracts using Whatman filter paper No.1. Extracts were then evaporated at $50^{\circ} \mathrm{C}$. The dry and sticky extracts were refrigerated until further use.

\section{Organic extract:-}

$5 \mathrm{gm}$ of dry peel powder were added in different solvents. Extraction was allowed to stand in orbital shaker at 100 rpm $\left(25^{\circ} \mathrm{C}\right)$ for 24 hours, after whichthey were filtered using Whatman filter paper No.1. Extracts werethen evaporated at $50^{\circ} \mathrm{C}$. The dry and sticky extracts wererefrigerated until further use.

\section{Qualitative phytochemical screening:-}

Petroleum ether, chloroform, ethyl acetate, methanol, ethanol, butanol, acetone, hydroxymethanol, hydroxyethanol and distilled water extracts of Lagenaria siceraria (Molina) Standl. and Luffa cylindrica (L.) M.Roem. peel powdered samples were tested for the presence or absence of various phytochemicals using standard methods.

\section{Test for Carbohydrates:-}

To $1 \mathrm{ml}$ of the extract, $0.5 \mathrm{ml}$ of $\alpha$-napthol solution was added. After 2-3 mins incubation, $2 \mathrm{ml}$ of concentrated sulphuric acid was added through the sides of the test tube. Formation of reddish violet color at the junction of the two liquids revealed the presence of carbohydrates.

\section{Test for Amino Acids:-}

Two drops of freshly prepared $0.2 \%$ ninhydrin reagent was added to the $2 \mathrm{ml}$ of extract solution and boiled for 2 mins. Development of violet ring revealed the presence of amino acids.

\section{Test for Protein:-}

To $1 \mathrm{ml}$ of extracts add $1 \mathrm{ml}$ of alkaline sodium carbonate solution and 2 drops of $1 \%$ copper sulphate solution. Formation of blue color indicated the presence of proteins.

Test for Alkaloids:-

To $1 \mathrm{ml}$ of extract, $1 \mathrm{ml}$ of Dragendroff's reagent was added. An orange-red precipitate indicated the presence of alkaloid. 


\section{Test for Cardiac glycosides:-}

To $1 \mathrm{ml}$ of extracts, $1 \mathrm{ml}$ of glacial acetic acid containing $2.5 \mathrm{ml}$ of ferric chloride solution was added. Carefully 2 $\mathrm{ml}$ of concentrated sulphuric acid was added. A reddish brown layer forms at the junction of the two liquids and the upper layer slowly becomes bluish green, darkening with standing indicated presence of cardiac glycosides.

\section{Test for Terpenoid:-}

$1 \mathrm{ml}$ of chloroform was added to $2 \mathrm{ml}$ of each extract followed by a few drops of concentrated sulphuric acid. A reddish brown precipitate produced immediately indicated the presence of terpenoids.

\section{Test for phenols:-}

An aliquot of the extract was mixed with $5 \mathrm{ml}$ Folin-Ciocalteu reagent and $4 \mathrm{ml}$ of sodium carbonate. The tubes were vortexed for $15 \mathrm{sec}$ and allowed to stand for $30 \mathrm{~min}$ at $40^{\circ} \mathrm{C}$ for colour development. An appearance of blue colour showed the presence of phenols.

\section{Test for Flavonoids:-}

$2 \mathrm{ml}$ of extracts was treated with few drops of $20 \%$ sodium hydroxide solution. Formation of intense yellow colour, which becomes colourless on addition of dilute hydrochloric acid, indicated the presence of flavonoids.

\section{Test for Saponins:-}

$1 \mathrm{ml}$ of extracts was shaken with $2 \mathrm{ml}$ of distilled water vigorously 5 minutes. Formation of foam indicated the presence of saponins.

\section{Test for Tannins:-}

To $1 \mathrm{ml}$ of the extracts, $1 \mathrm{ml}$ of $5 \%$ ferric chloride solution was added. Formation of dark blue or bluish black color showed the presence of tannins.

\section{Test for Anthraquinone:-}

To $1 \mathrm{ml}$ of extracts, $1 \mathrm{ml}$ of $1 \%$ potassium hydroxide solution was added. Formation of orange to yellow colour indicates presence of anthraquinone.

\section{Test for Phlobatannins:-}

About $2 \mathrm{ml}$ of extract was added to $2 \mathrm{ml}$ of $1 \% \mathrm{HCl}$ and the mixture was boiled. Deposition of a red precipitate was taken as an evidence for the presence of phlobatannins.

\section{Tests for Steroids:-}

Development of a greenish colour when $2 \mathrm{ml}$ of the organic extract was dissolved in $2 \mathrm{ml}$ of chloroform and treated with sulphuric and acetic acid showed the presence of steroids.

\section{Test for Phytosterols:-}

A little quantity of the extract was dissolved in $5 \mathrm{ml}$ of chloroformseparately. This chloroform solution was treated with a few drops ofconcentrated sulphuric acid. To this a few drops of dilute acetic acidand $3 \mathrm{ml}$ of acetic anhydride was added. A bluish green colourconfirmed the presence of phytosterols.

\section{Result and Discussion:-}

Each extract was subjected to phytochemical screening and variousphytoconstituents were found to be present in different extracts of Lagenaria siceraria(Molina) standl. and Luffa cylindrica (L.) M.Roem.peels(Table 1,2,3 and 4).

Carbohydrates were found to be present in all the extracts of Lagenaria siceraria(Molina) standl. and Luffa cylindrica(L.)M.Roem.peels. Amino acids and proteins were found to be present in aqueous, methanolic, ethanolic, hydroxyethanolic, hydroxymethanolic and acetone extract of Lagenaria siceraria Molina standl. and Luffa cylindrica (L.) M.Roem.peels and were absent in butanol, petroleum ether, ethylacetate and chloroform extracts.

Flavonoids were found to be present in all the extracts of Lagenaria siceraria(Molina) standl. peels whereas in case of Luffa cylindrica (L.) M.Roem. peels, flavonoids were present in all the extracts of Luffa cylindrica (L.) M.Roem.peels except in chloroform extract. Alkaloids were found to be present in aqueous, methanolic, ethanolic, 
hydroxyethanolic, hydroxymethanolicextracts of Lagenaria siceraria Molina standl. and Luffa cylindrica (L.) M.Roem.peels.

Saponins were found to be present in aqueous extract of Lagenaria siceraria Molina standl. and Luffa cylindrica (L.) M.Roem.peels.Phenols were found to be present in all the extracts of Lagenaria siceraria Molina standl. and Luffa cylindrica (L.) M.Roem.peels except in petroleum ether and chloroform extracts.

Tannins were found to be present in aqueous, methanolic, ethanolic, hydroxyethanolic, hydroxymethanolicextracts of Lagenaria siceraria(Molina) standl. and Luffa cylindrica (L.)M.Roempeels. Phlobatannins were absent in all the extracts of Lagenaria siceraria(Molina) standl. and Luffa cylindrica L. M.Roem.peels.

Cardiac glycosides were found to be present in all the extracts of Lagenaria siceraria Molina standl. and Luffa cylindrica L. M.Roempeels except in petroleum ether extract. Phytosterols were present in methanolic and acetone extract of Lagenaria siceraria(Molina) standl. and only in the acetone extract of Luffa cylindrica (L.) M.Roem.peels.

Steroids and terpenoids were found to be present in all the extracts of Lagenaria siceraria(Molina) standl. and Luffa cylindrica (L.) M.Roem.peels except in petroleum ether extract.

Anthraquinone were found to be present in aqueous, methanolic, ethanolic, hydroxyethanolic, hydroxymethanolic and acetone extracts Lagenaria siceraria(Molina) standl. and Luffa cylindrica( L.) M.Roem.peels.

Table 1:- Preliminary phytochemical analysis of different extracts of Lagenaria siceraria (Molina) Standl. vegetable peel

\begin{tabular}{|c|c|c|c|c|c|c|}
\hline \multirow{2}{*}{ Sr. No. } & Phytochemical & \multicolumn{3}{|c|}{ Lagenaria siceraria (Molina) Standl. vegetable peel extracts } \\
\cline { 3 - 6 } & & AE & ME & EE & HME & HEE \\
\hline 1. & Carbohydrates & + & + & + & + & + \\
\hline 2. & Proteins & + & + & + & + & + \\
\hline 3. & Amino Acids & + & + & + & + & + \\
\hline 4. & Alkaloids & + & + & + & + & + \\
\hline 5. & Flavonoids & + & + & + & + & + \\
\hline 6. & Saponins & + & - & - & - & - \\
\hline 7. & Phenols & + & + & + & + & + \\
\hline 8. & Anthraquinones & + & + & + & + & + \\
\hline 9. & Tannins & + & + & + & + & + \\
\hline 10. & Cardiac Glycosides & + & + & + & + & + \\
\hline 11. & Phlobatannins & - & - & - & - & - \\
\hline 12. & Steroids & + & + & + & + & + \\
\hline 13. & Terpenoids & + & + & + & + & + \\
\hline 14. & Phytosterols & - & + & - & - & + \\
\hline
\end{tabular}

Keys: +: Present and - : Absent

Keyword: AE: Aqueous extract; ME: Methanolic extract; E: Ethanolic extract; HME: Hydroxy Methanolic extract and HEE: Hydroxy Ethanolic extract 
Table 2:- Preliminary phytochemical analysis of different extracts ofLagenaria siceraria (Molina) Standl. vegetable peel

\begin{tabular}{|c|l|c|c|c|c|c|}
\hline \multirow{2}{*}{ Sr. No. } & \multirow{2}{*}{ Phytochemical } & \multicolumn{5}{|c|}{ Lagenaria siceraria (Molina) Standl. vegetable peel extracts } \\
\cline { 3 - 7 } & & BE & PE & EAE & CE & ACE \\
\hline 1. & Carbohydrates & + & + & + & + & + \\
\hline 2. & Proteins & - & - & - & - & + \\
\hline 3. & Amino Acids & - & - & - & - & + \\
\hline 4. & Alkaloids & - & - & - & - & - \\
\hline 5. & Flavonoids & + & + & + & + & + \\
\hline 6. & Saponins & - & - & - & - & - \\
\hline 7. & Phenols & + & - & + & - & + \\
\hline 8. & Anthraquinones & - & - & - & - & + \\
\hline 9. & Tannins & - & - & - & - & - \\
\hline 10. & Cardiac Glycosides & + & - & + & + & + \\
\hline 11. & Phlobatannins & - & - & - & - & - \\
\hline 12. & Steroids & + & - & + & + & + \\
\hline 13. & Terpenoids & + & - & + & + & + \\
\hline 14. & Phytosterols & - & - & - & - & + \\
\hline
\end{tabular}

Keys: +: Present and - : Absent

Keyword: BE: Butanol extract; PE: Petroleum ether extract; EAE: Ethyl acetate extract; CE: Chloroform extract and ACE: Acetone extract

Table 3:- Preliminary phytochemical analysis of different extracts of Luffa cylindrica (L.) M.Roem. vegetable peel

\begin{tabular}{|c|l|c|c|c|c|c|}
\hline \multirow{2}{*}{ Sr. No. } & \multirow{2}{*}{ Phytochemical } & \multicolumn{4}{|c|}{ Luffa cylindrica (L.) M.Roem. vegetable peel extracts } \\
\cline { 3 - 7 } & & AE & ME & EE & HME & HEE \\
\hline 1. & Carbohydrates & + & + & + & + & + \\
\hline 2. & Proteins & + & + & + & + & + \\
\hline 3. & Amino Acids & + & + & + & + & + \\
\hline 4. & Alkaloids & + & + & + & + & + \\
\hline 5. & Flavonoids & + & + & + & + & + \\
\hline 6. & Saponins & + & - & - & - & - \\
\hline 7. & Phenols & + & + & + & + & + \\
\hline 8. & Anthraquinones & + & + & + & + & + \\
\hline 9. & Tannins & + & + & + & + & + \\
\hline 10. & Cardiac Glycosides & + & + & + & + & + \\
\hline 11. & Phlobatannins & + & - & - & - & - \\
\hline 12. & Steroids & + & + & + & + & + \\
\hline 13. & Terpenoids & - & + & + & + & + \\
\hline 14. & Physterols & & + & - & - & - \\
\hline
\end{tabular}

Keys: +: Present and - : Absent

Keyword: AE: Aqueous extract; ME: Methanolic extract; E: Ethanolic extract; HME: Hydroxy Methanolic extract and HEE: Hydroxy Ethanolic extract 
Table 4:- Preliminary phytochemical analysis of different extracts of Luffa cylindrica (L.) M.Roem.vegetable peel

\begin{tabular}{|c|c|c|c|c|c|c|}
\hline \multirow[t]{2}{*}{ Sr. No. } & \multirow[t]{2}{*}{ Phytochemical } & \multicolumn{5}{|c|}{ Luffa cylindrica (L.) M.Roem. vegetable peel extracts } \\
\hline & & BE & PE & EAE & $\mathbf{C E}$ & ACE \\
\hline 1. & Carbohydrates & - & + & - & - & - \\
\hline 2. & Proteins & - & - & - & - & + \\
\hline 3. & Amino Acids & - & - & - & - & + \\
\hline 4. & Alkaloids & - & - & - & - & - \\
\hline 5. & Flavonoids & + & + & + & - & + \\
\hline 6. & Saponins & - & - & - & - & - \\
\hline 7. & Phenols & + & - & + & - & + \\
\hline 8. & Anthraquinones & - & - & - & - & + \\
\hline 9. & Tannins & - & - & - & - & - \\
\hline 10. & Cardiac Glycosides & + & - & + & + & + \\
\hline 11. & Phlobatannins & - & - & - & - & - \\
\hline 12. & Steroids & + & - & + & + & + \\
\hline 13. & Terpenoids & + & - & + & + & + \\
\hline 14. & Phytosterols & - & - & - & - & + \\
\hline
\end{tabular}

Keys: +: Present and - : Absent

Keyword: BE: Butanol extract; PE: Petroleum ether extract; EAE: Ethyl acetate extract; CE: Chloroform extract and ACE: Acetone extract

\section{Conclusion:-}

Recycling of fruit and vegetable waste is one of the most important means of utilizing it in a number of innovative ways yielding new products. The secondary metabolites (phytochemicals) and other chemical constituents of medicinal plants account for their medicinal value. The phytochemical evaluation can be used for further assessment of secondary metabolites. The preliminary phytochemical tests are helpful in finding chemical constituents in the plant material that may lead to their quantitative estimation and also in locating the source of pharmacologically active chemical compound.

\section{References:-}

1. CK Atal, ML Sharma and Khariya, A J of Ethnopharmacology, 1986, 18: 133-141.

2. JC Okaka, ENT Akobundu and ANC.Okaka, Human nutrition: An Integrated Approach. 2 ed. OCJANCO Academic Publishers, Enugu (2002)312-320.

3. S Okonogi, C Duangrat, S Anuchpreeda, S Tachakittirungrod and S Chowwanapoonpohn, Food Chem., 2007, 103: 839-846.

4. V. Singh and A.N. Garg, Food Chemistry, 2006, 94(1): 81-89.

5. O Vasso, R Winfried, Springer, 2007, 3.

6. K. Nand: Recent advances in the treatment of liquid and solid wastes of food processing industries for biogas production and pollution abatenront. Proc. 4th International. Food Convention, Mysore,(1998)35. 